\title{
A New Entity: Chiari Zero Malformation and Its Surgical Method
}

\section{Yeni Bir Tanum: Chiari Sufir Malformasyonu ve Onun Cerrabi Tedavisi}

\author{
Nejat ISIK ${ }^{1}$, Ilhan ELMACI ${ }^{1}$, Mustafa KAKSI ${ }^{1}$, Bekir GOKBEN ${ }^{1}$, Nihal ISIK ${ }^{2}$, Melek CELIK $^{3}$ \\ ${ }^{1}$ M.H. Goztepe Education and Research Hospital, Department of Neurosurgery, Istanbul, Turkey \\ ${ }^{2} M . H$. Goztepe Education and Research Hospital, Department of Neurology, Istanbul, Turkey \\ ${ }^{3}$ M.H. Goztepe Education and Research Hospital, Department of Anaesthesiology and Reanimation, Istanbul, Turkey
}

Correspondence address: Nejat ISIK / E-mail: nejatisik@yahoo.com

\begin{abstract}
Recently, Iskandar et al described "Chiari Zero malformation" to characterize some kind of syringomyelia that exhibits classic Chiari-type symptoms with little to no herniation, but there is some dilemma about whether it is actually present. We presented a 38-year-old-man with a diagnosis of cervical syringomyelia. In his neurological examination, there was monoparesia at the left leg together with hypoesthesia below thoracal 7. He had initially been treated with syringopleural shunting successfully. Nine months after surgery, his syringomyelia had regrown and he clinically deteriorated. It was accepted as "a Chiari zero malformation". We performed craniovertebral decompression only. Although there was no tonsillar herniation, his syringomyelia was completely resolved and his neurological status was improved six months after the craniovertebral decompression, This case suggested that "Chiari zero malformation" description is remarkable and craniovertebral decompression is a suitable surgical approach for this entity.
\end{abstract}

KEYWORDS: Chiari type 1 malformation, Chiari zero malformation, Chiari-like malformation, Craniovertebral decompression, Syringomyelia, Syringopleural shunt

öz

Iskandar ve arkadaşları yakın zamanda, tonsil herniasyonu olmaksızın ya da minimal tonsil herniasyonu ile birlikte klasik chiari malformasyonu bulguları olan bazı siringomyeli çeşitlerini "Chiari zero malformation" (Chiari 0 malformasyonu) olarak tanımladılar, fakat tanımın doğruluğu hakkında hala kuşkular vardır. Servikal siringomyelisi olan 38 yaşında bir erkek hastayı sunduk. Başağrısına ilaveten, nörolojik incelemede sol bacakta monoparezi ve torakal 7 altında hipoestezi vardı. Siringoplevral şant ile başarılı bir şekilde tedavi edildi. Fakat 9 ay sonra kliniğinde yeniden bozulma oldu ve siringomyelisinde artma oldu. Hasta "Chiari 0 malformasyonu" düşünülerek yalnızca kranyovertebral dekompresyon yapıldı. Tonsil herniasyonu olmamasına rağmen kranyovertebral dekompresyon ile, 6 ay içinde kliniği ve başağrısı tamamen geçti, siringomyelisi küçüldü. Bu olgu "Chiari 0 malformasyonu" tanımının değerli olduğunu ve kranyovertebral dekompresyonun bu tanı için uygun tedavi olduğunu destekledi.

ANAHTAR SÖZCÜKLER: Chiari malformasyonu tip 1, Chiari sıfır malformasyonu, Chiari benzeri malformasyon, Kranyovertebral dekompresyon, Siringomyeli, Siringoplevral şant

\section{INTRODUCTION}

When Hans Chiari first wrote about the Chiari malformations, he identified four different types based upon what brain structures were displaced out of the skull (3). Today, defining exactly what Chiari means is not an easy task $(11,12)$. Most people define Chiari as tonsillar herniation of greater than $3 \mathrm{~mm}-5 \mathrm{~mm}$. Herniation is measured as the distance below the foramen magnum $(11,12)$.

While this definition is still widely used, authors showed that the amount of tonsillar herniation is not related to severity of symptoms or clinical outcome in the Chiari malformation. Conversely, there are some patients with with syringomyelia who exhibit classic Chiari-type symptoms with little to no herniation $(3,11,12)$.
Recently, Iskandar and Tubbs et al. used "Chiari zero malformation" to characterize this kind of syringomyelia disorder and advised craniovertebral decompression (CVD) as the surgical modality $(8,9,16,17)$. There is a very limited number of papers on the "Chiari zero malformation", and there is a query about the truth of this pathology $(8,9,10,14,16,17,18)$.

We presented a patient with a diagnosis of Chiari zero malformation who was treated with combined syringopleural shunting and CVD.

\section{CASE REPORT}

A 38-year-old-man was admitted to our hospital with headache, throbbing nuchal pain and weakness of the left leg. The neurological examination presented hypoesthesia below T7-(reduced sensation of vibration and position ipsilaterally, 
and of pain and temperature contralaterally below the Th7 level together with inability to feel hot or cold), monoparesia at the left leg without spasticity and marked hyperactive patellar and Achilles reflexes. MRI revealed cervical syringomyelia extending from $\mathrm{C} 1$ to Th5 and associated small posterior fossa. There was no tonsillar herniation (Figure 1A,B).

He underwent syringopleural shunting via C5 and C6 laminectomy. Postoperatively, the syrinx collapsed and his clinical status was improved (Figure 2A). Nine months after surgery, his clinical status deteriorated. He was also suffering from headaches at times that were especially aggravated while coughing and straining while defecating. In his neurological examination, there was hypoesthesia below Th7 level together with slight paresia of his left leg. MRI revealed that the cervical syringomyelia regrowth extended from $C 1$ to $C 5$ although the shunt was functional (Figure 2B). There was no tonsillar herniation, but the cerebellum and cerebellar tonsils filled the posterior fossa to capacity and the brain stem and cistern of the posterior fossa was compressed. Posterior fossa linear and volume measurements were performed according to the Tubbs and Furtado studies $(5,16)$. The distance from the basion to the opisthion was $38 \mathrm{~mm}$, and the tip of the obex was found to be at $4.0 \mathrm{~mm}$ superior to the foramen magnum. The midsagittal horizontal distance of the spinomedullary junction at a midpoint on a line connecting the basion to the opisthion was $13 \mathrm{~mm}$. The distance from the fastigium to the floor of the fourth ventricle was $9.0 \mathrm{~mm}$. The horizontal distance from the spheno-occipital synchondrosis to the basis pontis was $3.0 \mathrm{~mm}$. The width of the posterior cranial fossa was $9.5 \mathrm{~cm}$, the anteroposterior dimension was 6 $\mathrm{cm}$ and the height was $5 \mathrm{~cm}$. The PFV was $205.3 \mathrm{~cm}^{3}$ and ICV was $1002.66 \mathrm{~cm}^{3}$. The PFV to ICV ratio was 0.204 . (rev6)

Cine MRI showed that there was a CSF flow block at the craniovertebral junction. Brainstem evoked potentials (BAEP) also showed that there was low brainstem dysfunction manifesting prolongation of I-III interpeak latency (IPL).

We accepted the patient to have a Chiari Zero malformation. CVD was performed with the patient in supine position, and dural grafting was performed with bovine pericardium. Postoperatively, the clinical status was improved. Immediately after surgery, the headache and nuchal pain remitted. The postoperative MRI depicted the large created cisterna magna, enlargement of the fourth ventricle as well as of the superior and prepontine cistern. During the follow-up, MRI six months after surgery revealed that the syrinx had collapsed again (Figure 3A,B).

One year later, the patient continued without headache, nuchal pain and left monoparesia but the hyperactive patellar and Achilles reflexes remained unchanged. Cine MRI showed that CSF flow was normal in the craniovertebral junction, and BAEP also revealed improvement in I-III IPL.

\section{DISCUSSION}

In 1997, Iskandar et al. presented five children with syringohydromyelia, where clinical and radiological resolution was demonstrated after posterior fossa decompression, at the 47th Meeting of the AANS/CNS Joint Section of Paediatric Neurosurgery (6). None of the patients had hindbrain herniation. Their course was similar to that of patients
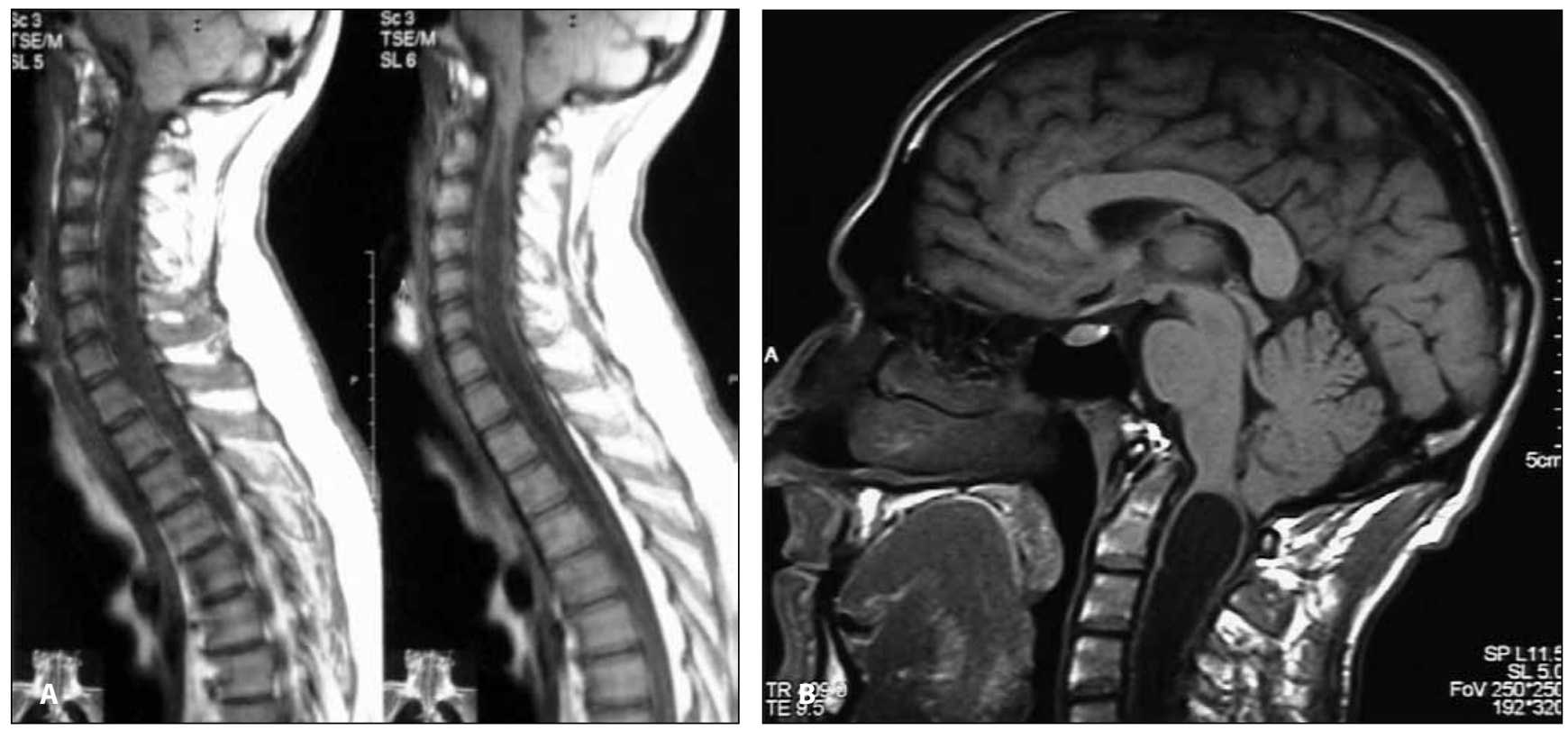

Figure 1: A) T1-weighted sagittal MR images of the craniocervical junction, showing the midline structures of the posterior cranial fossa and the brainstem and the cerebellum, cervical syringomyelia. The cisterna magna is completely obliterated by the thickened posterior rim of the foramen magnum. Note the lack of hindbrain herniation. There is a CSF block at the inferior pole of the cerebellar tonsils. B) Preoperative sagittal T1-weighted craniocervicospinal MRI shows impacted cisterna magna, diminished fourth ventricle and cervicothoracal syringomyelia. 

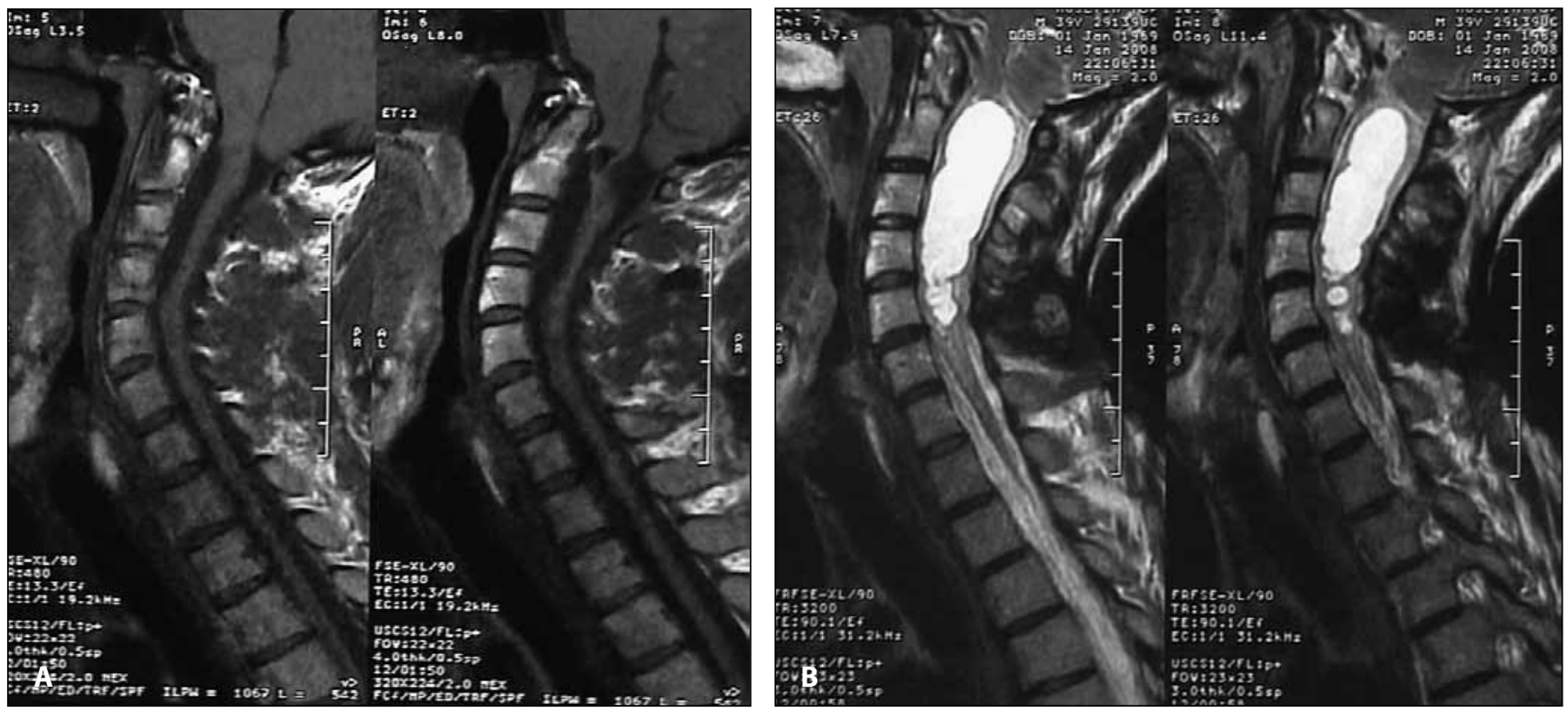

Figure 2: A) Early Postoperative T1-weighted sagittal MRI showing collapsed syringomyelia after syringopleural shunting, There is no CSF block at the inferior pole of the cerebellar tonsils. B) Postoperative T2-weighted sagittal MRI showing regrowth of syringomyelia 9 months after SP shunting. There is a CSF block at the inferior pole of the cerebellar tonsils.
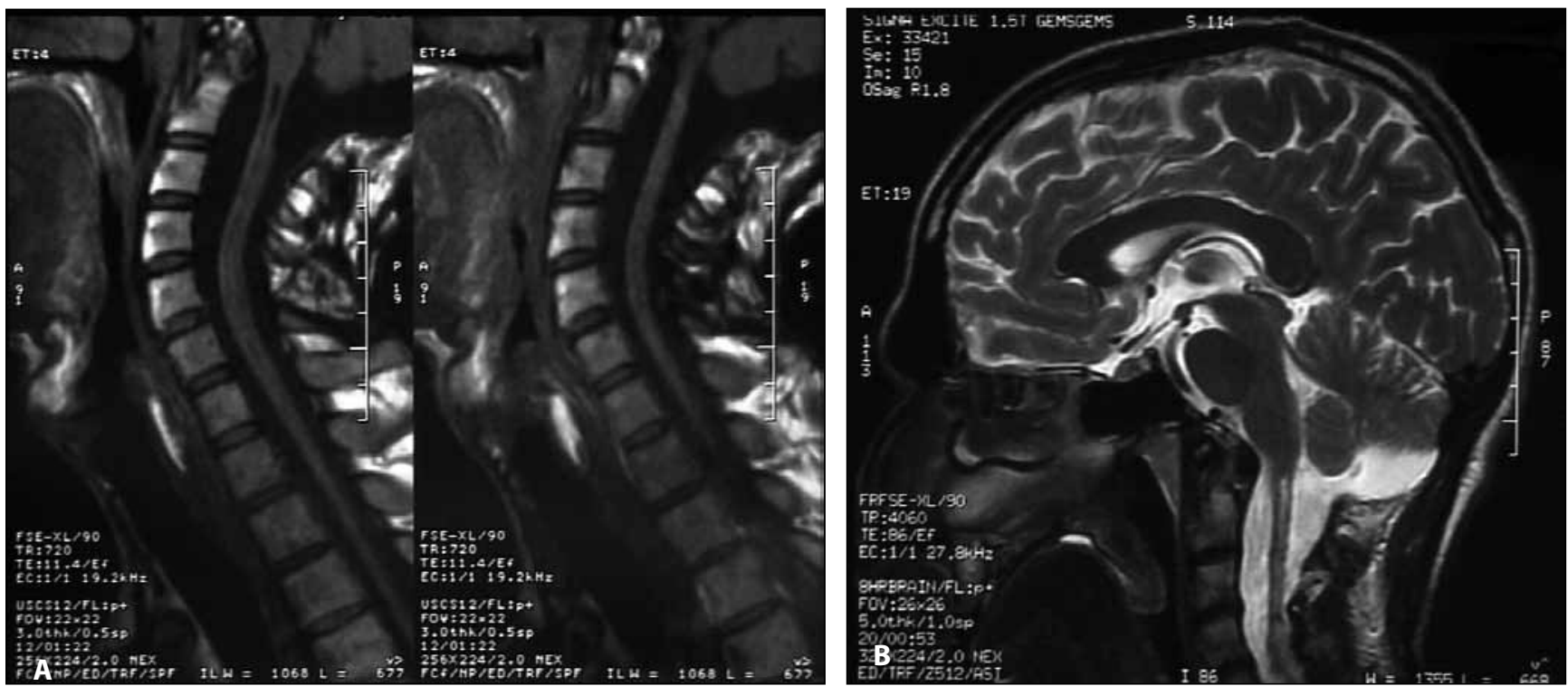

Figure 3: A) Postoperative sagittal T1-weighted cranial MRI showing the newly created cisterna magna, opening of the fourth ventricle and enlargement of the cisternae magna, and superior and prepontine cisternae. and collapse of the syringomyelia 6 months after craniovertebral decompression was added to syringopleural shunting. B) Postoperative sagittal T2-weighted craniovertebral MRI showing the artificial mega cisterna magna, and collapsed syringomyelia, and functional shunt 6 months after craniovertebral decompression.

with Chiari malformation. In cases in which preoperative cine-MR imaging was performed, decreased or normal-todecreased flow was demonstrated $(6,7,8)$. Four years later, Tubbs, et al. added a sixth case and found that even in the absence of tonsillar ectopia, the obices were located more than two standard deviations below normal (16). "Chiari zero malformation" was the name they chose to characterize the disorder. In 2004, Tubbs added 7th case to this series [17].
Today, Chiari 0 is a kind of syringohydromyelia, but with minimal findings of hindbrain herniation, or it is a term used when a patient is symptomatic but the herniation extends less then $5 \mathrm{~mm}$ and is associated with syringomyelia. Synonyms are "Chiari-like pathophysiology", and "borderline Chiari" $(6,7,12,14,15,18)$. Some authors describe this disorder as "tight cisterna magna" (10). 
There are some questions and dilemmas regarding the subject: 1 . Is it a physiological or anatomic abnormality?; 2. What is the method of detection or diagnosis?; 3 . What is the prevalence?; and 4. What is the suitable treatment? $(8,18)$.

In 1999, Milhorat, et al. studied 364 symptomatic patients with Chiari I malformation (12). They found tonsillar ectopia of less than $5 \mathrm{~mm}$ in 32 (9\%) of the 364 symptomatic patients, but compression of the CSF spaces posterior and lateral to the cerebellum was present in all cases. In fact the tonsils were at the level of the foramen magnum in the illustrative case they presented.

In 2000 Meadows, et al, published a review of 22,591 patients in whom MR imaging was performed (11). Tonsillar herniation extending more than $5 \mathrm{~mm}$ below the foramen magnum was found in $0.77 \%$. Fourteen percent of those patients were asymptomatic (with 7-25 mm of ectopia) and 25\% of those had peg-like tonsils. The authors concluded that "isolated tonsillar herniation is of limited prognostic utility, and should be considered in the context of all available clinical and imaging data."

This limited usefulness of tonsillar herniation in defining Chiari has led many experts to base their diagnoses not solely on MRI's, but rather on a combination of MRI, cine $\mathrm{MRI}$, symptoms, neurological examination, and their own experience $(1,2,4,6,7,11,13,15,18)$.

Based on the review of all these papers the following remarks can be made. 1) Radiologically significant tonsillar ectopia may be completely asymptomatic. 2) There are patients in whom the tonsillar herniation extends less than $5 \mathrm{~mm}$ from the foramen magnum, whose clinical behaviour is similar to the remainder of the Chiari population, including even those with radiological evidence of syringohydromyelia.

Dr. Sekula and Dr. Jannetta, have extended this line of research and shown that so-called Chiari like patients (or Chiari 0 Malformation) tend to have small posterior fossa, similar to Chiari I patients (13). In this group, MRI reveals syringomyelia without tonsillar herniation, and a small posterior fossa. The obex is significantly lower than normal. Other reported abnormal anatomic findings in Chiari 0 malformation are increased AP diameter of the foramen magnum, increased AP distance of spinomedullary junction to the foramen magnum, and increased angle between the floor of the 4th ventricle and clivus. The measurements of our patient were similar to this study. This and other studies have led to the theory that Chiari is not a disorder of the brain, but rather a result of the skull being too small for a normal sized brain (post neurulation defect) $(5,8,13,14,16,18)$.

Symptoms are caused by a blockage in CSF flow in this pathology as in CM type I. Cine MRI can show the CSF blockage at the craniovertebral junction. It is generally accepted that the presence of a syringomyelia with Chiari type 1 malformation is a strong indication for surgical decompression as the syrinx will progress, even if it is asymptomatic $(6,8,11,14)$, BAEP may be used to show brainstem compression although there was no tonsillar herniation such as our case. Although there is inadequate information in the literature, it should be an important tool to diagnose the Chiari 0 malformation.

Together with this pathology, most surgeons have found osseous abnormalities, (posterior arch defect of C1 \& C2, assimilation of post arch of (1), soft tissue abnormalities (intradural adhesions, fourth ventricular "veil"), tonsils crowding the foramen magnum, and tonsils protruding mildly below the foramen magnum. They believe that operating with craniovertebral decompression on "Chiari zero malformation" patients associated with syringomyelia, is also beneficial, while others remain sceptical $(6,7,8,10,14)$. In our case, there were also extra and intradural adhesions at the small posterior fossa. It suggested that craniovertebral decompression is beneficial

\section{CONCLUSIONS}

Measurements of posterior fossa and CSF flow at the craniovertebral junction, and BAEP can be used to diagnose "Chiari zero malformation". Craniovertebral decompression seems to be the best initial approach for this entity as it addresses the underlying pathophysiology of an alteration in normal CSF flow patterns. We think that this is a valuable description of the Chiari zero malformation but more prospective reported cases with long term outcome are needed.

\section{REFERENCES}

1. Armonda RA, Citrin CM, Foley KT, Ellenbogen RG: Quantitative cinemode magnetic resonance imaging of Chiari I malformations: An analysis of cerebrospinal fluid dynamics. Neurosurgery 35 : 214-224, 1994

2. Bhadelia RA, Bogdan AR, Wolpert SM, Lev S, Appignani BA, Heilman CB: Cerebrospinal fluid flow waveforms: Analysis in patients with Chiari I malformation by means of gated phasecontrast MR imaging velocity measurements. Radiology 196 : 195-202, 1995

3. Chiari H: Über Veränderungen des Kleinhirns, des Pons und der Medulla oblongata in Folge von congenitaler Hydrocephalie des Grosshirns. Denkschr Akad Wiss 63:71-116, 1895

4. Elster $A D$, Chen MY: Chiari I malformations: Clinical and radiologic reappraisal. Radiology 183(2):347-353, 1992

5. Furtado SV, Reddy K, Hegde AS: A Posterior fossa morphometry in symptomatic pediatric and adult Chiari I malformation. Clinical Study. Journal of Clinical Neuroscience 16:1449-1454, 2009

6. Hofmann E, Warmuth-Metz M, Bendszus M, Solymosi L: Phasecontrast MR imaging of the cervical CSF and spinal cord: Volumetric motion analysis in patients with Chiari I malformation. AJNR 21:151-158, 2000

7. Hofkes SK, Iskandar BJ, Turski PA, Gentry LR, McCue JB, Haughton VM: Differentiation between symptomatic Chiari I malformation and asymptomatic tonsillar ectopia by using cerebrospinal fluid flow imaging: initial estimate of imaging accuracy. Radiology 245(2):532-540, 2007

8. Iskandar BJ, Hedlund GL, Grabb PA, Oakes WJ: The resolution of syringohydromyelia without hindbrain herniation after posterior fossa decompression. J Neurosurg 89:212-216, 1998 
9. Iskandar BJ, Hedlund GL, Grabb PA, Oakes J: The resolution of syringohydromyelia without hindbrain herniation after posterior fossa decompression. Neurosurg Focus 8(3): Article 5, 2000

10. Kyoshima K, Kuroyanagi T, Oya F, Kamijo $Y$, El-Noamany $H$, Kobayashi S: Syringomyelia without hindbrain herniation: Tight cisterna magna: Report of four cases and review of the literature. J Neurosurg 96:239-249, 2002

11. Meadows J, Kraut M, Guarnieri M, Haroun RI, Carson BS: Asymptomatic Chiari Type I malformations identified on magnetic resonance imaging. J Neurosurg 92:920-926, 2000

12. Milhorat TH, Chou MW, Trinidad EM, Kula RW, Mandell M, Wolpert C, Speer MC: Chiari I malformation redefined: Clinical and radiographic findings for 364 symptomatic patients. Neurosurgery 44:1005-1017, 1999

13. Sekula RF Jr, Jannetta PJ, Casey KF, Marchan EM, Sekula LK, McCrady CS: Dimensions of the posterior fossa in patients symptomatic for Chiari I malformation but without cerebellar tonsillar descent. Cerebrospinal Fluid Res. 2(1):11, 2005. Available at http://www.cerebrospinalfluidresearch.com/content/2/1/11
14. Silva JAG, Costa MDL, Melo LRS, Araújo AF, Almeida EB: Impacted cisterna manga without syringomyelia associated with lancinating headache, throbbed nuchal pain and paraparesis treated by posterior fossa decompression. Arq Neuropsiquiatr 65(4-B): 1228-1232, 2007

15. Terae S, Miyasaka K, Abe S, Abe H, Tashiro K: Increased pulsatile movement of the hindbrain in syringomyelia associated with the Chiari malformation: Cine-MRI with presaturation bolus tracking. Neuroradiology 36:125-129, 1994

16. Tubbs RS, Elton S, Grabb P, Dockery SE, Bartolucci AA, Oakes WJ: Analysis of the posterior fossa in children with the Chiari 0 malformation. Neurosurgery 48:1050-1055, 2001

17. Tubbs RS, Wellons JC, Blount JP, Oakes WJ: Syringomyelia in Twin Brothers Discordant for Chiari I Malformation: Case Report. Journal of Child Neurology 19(6):459-462, 2004 [DOI: 10.1177/088307380401900613]

18. Is Chiari 0 for real? Research shows small posterior fossa in Chiari 0 patients. Small posterior Fossa found in Chiari 0 Patients. [conquer chiari web site] [serial online]. January, Volume 4, Number 1, 2006 Available at http://www.conquerchiari.org/ index.htm. (database) 